\title{
Some legal issues on compensation for environmental damage under Vietnamese law and the law of the European Union
}

\author{
Pewne kwestie prawne dotyczące odszkodowania za szkody w środowisku \\ na podstawie prawa wietnamskiego i prawa Unii Europejskiej \\ Некоторые правовые вопросы компенсации вреда, причиненного окружающей \\ среде на основании законодательства Вьетнама и Европейского Союз
}

\author{
TRAN CONG THIET \\ M.A., PhD student, University of Warsaw \\ e-mail: congthiet1202@gmail.com, https://orcid.org/0000-0002-1504-7122
}

\author{
VU THI DUYEN THUY \\ Assoc. Prof. Dr, Hanoi Law University \\ e-mail: vuduyenthuy@gmail.com, https://orcid.org/0000-0002-0491-9183
}

\begin{abstract}
Summary: In recent years, the law on environmental damage compensation has been a burning issue in many countries around the world, especially in developing nations where the dilemma concerns the balance between economic development and environmental protection. The issue of liability for environmental damage can be considered from many perspectives, and the focus of this study will be civil liability compensation. Learning and studying the regulations of developed countries like the European Union plays an important role in the development and improvement of environmental laws in general and the law on environmental compensation in particular for Vietnam. In this article, the authors provide insights on some legal provisions on compensation for environmental damage based on comparison with the laws of the European Union to determine how to develop legal regulations in the field of environmental damage compensation. This creates a foundation that contributes to the introduction of solutions to improve the efficiency of the law on environmental damage compensation in Vietnam.
\end{abstract}

Key words: environmental damage, environmental damage compensation, EU directive on compensation, the indemnifiers, Environmental insurance

Streszczenie: W ostatnich latach ustawa o odszkodowaniu za szkody w środowisku była palącą kwestią w wielu krajach na całym świecie, zwłaszcza w krajach rozwijających się, gdzie dylemat dotyczy równowagi między rozwojem gospodarczym a ochroną środowiska. Kwestię odpowiedzialności za szkody w środowisku można rozpatrywać z wielu perspektyw. Przedmiotem niniejszego opracowania będzie odszkodowanie z tytułu odpowiedzialności cywilnej. Poznanie i zbadanie przepisów krajów rozwiniętych, takich jak te należące do Unii Europejskiej, odgrywa ważną rolę w opracowywaniu i doskonaleniu prawodawstwa dotyczącego ochrony środowiska w ujęciu ogólnym oraz ustawy o kompensacji środowiskowej dla Wietnamu w szczególności. W artykule autorzy przedstawiają spostrzeżenia w zakresie niektórych przepisów prawnych dotyczących odszkodowań za szkody w środowisku na podstawie porównania z prawem Unii Europejskiej w celu określenia sposobu kształtowania regulacji prawnych w zakresie odszkodowań za szkody w środowisku. Przyczynia się to do stworzenia fundamentu dla wprowadzenia rozwiązań poprawiających skuteczność ustawy o odszkodowaniu za szkody środowiskowe w Wietnamie.

Słowa kluczowe: szkody w środowisku, odszkodowanie za szkody w środowisku, dyrektywa UE w sprawie rekompensat, ubezpieczyciele, ubezpieczenie środowiskowe 
Резюме: В последние годы закон о компенсации вреда окружающей среде является актуальным вопросом во многих странах мира, особенно в развивающихся странах, где дилемма касается баланса между экономическим развитием и охраной окружающей среды. Вопрос ответственности за ущерб окружающей среде может рассматриваться с разных точек зрения, а предметом данной статьи будет вопрос гражданской ответственности. Ознакомление с законами развитых стран, например, Европейского Союза, и изучение их, играет важную роль в развитии и совершенствовании экологического законодательства в целом - и Закона о компенсации вреда, причиненного окружающей среде для Вьетнама в частности. В настоящей статье авторы дают представление о некоторых законах о компенсации вреда, причиненного окружающей среде на основе сравнения с законами Европейского Союза, с целью определения способов формирования правил возмещения ущерба окружающей среде. Это создает основу, способствующую внедрению решений для повышения эффективности Закона о компенсации вреда, причиненного окружающей среде во Вьетнаме.

Ключевые слова: вред, причиненный окружающей среде, компенсация за вред, причиненный окружающей среде, директива ЕС о компенсации, страховщики, экологическое страхование

\section{Introduction}

The environment is an extremely vast and complex entity and is suffering from harmful human impact, leading to the destabilization of the environment. Today, environmental issues tend to attract a lot of attention not only in Vietnam but also in many other countries throughout the world, regardless of whether it is a developed or a developing country. Depending on the specific contact of each country, there is a high likeliness of, and an increasing tendency for, environmental pollution, degradation and incidents that have diverse impacts on humans, flora and fauna. There are many different ways to protect the environment, prevent and limit environmental pollution, in which legal measures, including financial sanctions on polluters, play a very important role. In addition, the law on compensation for environmental damage has always been a prominent issue and received much attention from both domestic and international public opinion. In this article, the authors will engage in research to analyze the issues outlined below.

Firstly, the studies in this article examine environmental damage compensation as well as Environmental science theories such as "the polluter pays" and "the indemnified" by comparing the laws of Vietnam and those of the European Union.

Secondly, within the scope of the study, the authors also focused on the legality and practicality of methods of determining environmental damage by comparing the laws of Vietnam and the those of European Union. Besides, this article also looks at the system of regulations in the legal documents, only researching practical implementation at a relative level. Through these studies, the authors will propose solutions to guide the improvement of Vietnamese law on environmental damage compensation in civil cases. As we may know, compensation for damage is usually 
related to contractual and non-contractual agreements; however, within the scope of this article, the authors will not study contractual compensation, but instead focus on compensation for environmental damage caused by polluters, and the study of non-contractual civil liability compensation.

Finally, in this context, this article can be considered as a scientific study of the correlation and comparison of Vietnamese law with the European Union in some aspects of environmental damage compensation. According to the research and statistics unearthed by the authors, this is the first study in Vietnam on civil compensation for environmental damage involving both Vietnam and the European Union from a legal perspective, to be published in an international journal of environmental law. The conclusions and recommendations proposed by this article are scientific and applicable to the development and enforcement of laws on compensation for environmental pollution. The research finds of the authors aim to stand as a reference for legislative bodies in the process of researching, developing and completing the law on compensation for environmental pollution acts, as well as for research and teaching at law universities and colleges.

To summarize, systematic research of fundamental theoretical issues, a comprehensive review of the current legal provisions on environmental liability due to environmental pollution from a legal analysis of the European Union will offer Vietnam many valuable experiences and lessons for developing and improving Vietnamese law in general and the law on civil compensation for environmental damage in particular.

\section{The provisions of Vietnamese and European Union law on indemnifiers}

Liability to pay damage is a form of civil liability. ${ }^{1}$ This type of property liability applies to those who break the law. It forces the party causing damage to remedy the consequences by compensating for material and psychological losses to the affected party. ${ }^{2}$ In the field of environmental protection, the liability to compensate for damage by environmental pollution also applies in the form of civil liability,

T.T. Phung, Liability for non-contractual damage, Hanoi 2016.

$2 \mathrm{Vu}$ Thu Hanh, Tran Tien Anh, The right to sue for damage due to violations of environmental law in Vietnam - Legal basis and implementation process, Pannature, Hanoi 2011, p. 8. 
specifically the liability to pay non-contractual damage. ${ }^{3}$ EU law and Vietnamese law have certain similarities and differences in this matter as stated further.

\subsection{Principle for the determination of indemnifiers}

Regarding who is liable for compensation, both Vietnamese and EU law appears to be relatively similar. Accordingly, the determination of who is subject to liability for environmental damage compensation has been considered as a way to implement "the polluter pays" principle. The main objective of this practice is to make polluters liable for the damage caused by their acts. Damage means a measurable adverse change, identified in natural resources, or measurable degradation of the natural environment, when it is directly or indirectly affected. ${ }^{4}$ In addition, environmental damage also includes damage caused by airborne elements when they have a negative impact on water, soil or protected species in the natural environment. It can be simply understood that environmental damage is the damage of protected species living in the natural environment, ${ }^{5}$ this damage has an adverse effect on the protection and maintenance of species conservation and development. If the person causing the pollution needs to pay compensation for the damage caused by them, they will reduce the pollution to the point where the marginal cost reduction exceeds the compensation level to avoid. Therefore, the liability to compensate for environmental damage leads to the prevention of damage and the internalization of environmental costs. Hence, every individual or organization that causes a negative impact on the environment, causing negative consequences or endangering the environment, is liable for compensation for damage caused by their acts (collectively referred to as polluters).

The term "polluter" refers to a harmful activity caused by humans to the natural environment. However, "the polluter pays" principle mentioned above has inevitable consequences. EU law today generally defines polluters in a broader way. Not only actual "polluters" have to be strictly considered; those who (only) pose risks to the environment and do not (yet) pollute the environment should also be taken into account. And a question of whether "users" can also be considered as "polluters" is

3 H.N. Pham, Liability for compensation for environmental damage, State and Law Review 2008, no. 6.

4 Art. 1 of the Directive 2004/35/CE of the European Parliament and of the Council of 21 April 2004 on environmental liability with regard to the prevention and remedying of environmental damage, OJ L $143,30.04 .2004$.

5 No. 4 of the Directive 2004/35/CE of the European Parliament and of the Council of 21 April 2004 on environmental liability with regard to the prevention and remedying of environmental damage. 
relevant, particularly in the area of product control laws. When pollution control costs are included in product prices, users often pay indirectly. ${ }^{6}$

Directive 2004/35/CE of the European Parliament and of the Council of 21 April 2004 on environmental liability with regard to the prevention and remedying of environmental damage (ELD), Article 1 is based on the principle of "the polluter pays." However, it must be pointed out that, because one party clearly compensates the parties involved, irrespective of whether it is an individual or an organization - in general, the causal agents will have to pay damage - the directive does not establish a truly comprehensive and cross-border system of accountability for general application across the EU. On the other hand, the directive crosses the line between civil and administrative law. ${ }^{8}$ In Agusta, the European Court of Justice's strict liability regime does not violate the polluter pay principle according to the principle applicable to Directive 2004/35.

In Vietnam, there has not been any specific explanation in terms of the polluters and the principle of the polluter pays has not been officially mentioned in any legal documents, even though the approach of Vietnamese law also clearly demonstrates this view. For example, this principle was first expressed in the $1993^{9}$ Law on Environmental Protection, followed by the $2005^{10}$ Law on Environmental Protection. These regulations are an indirect recognition of the principle that polluters pay for environmental protection. ${ }^{11}$

Currently, as a specialized law in the field of environment, the Law on Environmental Protection 2014 clearly defines the principles of environmental protection

6 See Europe Commission, Workshop on Principles of EU Environmental Law, 2002, https://ec.europa.eu/ environment/legal/law/pdf/principles/1\%20Principles\%20Training\%20Guide.pdf [access: 15.03.2021].

7 In addition, the preamble of that directive stresses that the prevention and remedying of environmental damage should be implemented through the furtherance of the polluter-pays' principle and that, according to this principle, the operator should bear the cost of the necessary preventive or remedial measures (2nd and 18 th recitals of the preamble).

$8 \quad$ N. de Sadeleer, La directive 2004/35/CE relative à la responsabilité environnementale: avancée ou recul pour le droit de lenvironnement des Etats membres?, in: Les responsabilités environnementales dans l'espace Européen, eds. B. Dubuisson, G. Viney, Brussels 2005, p. 732.

9 Art. 7 of the Law on Environmental Protection 1993: Organizations and individuals that cause environmental damage due to their activities must compensate for damage according to the provisions of law.

10 Clause 5, art. 4 of the Law on Environmental Protection 1995: Organizations, households and individuals that cause environmental pollution and degradation are responsible for making good, compensating damage and other responsibilities according to the provisions of law.

11 V.T. Tin, Principles of polluter pays according to Vietnam's environmental law, PhD thesis in Law, Ho Chi Minh 2018, p. 40. 
and handling of environmental law violations in Articles $4{ }^{12}$ and $160 .{ }^{13}$ Accordingly, organizations, households and individuals that cause environmental pollution must make good, compensate for damage, and other liabilities in accordance with the law. Organizations and individuals that violate the law on environmental protection, causing pollution, degradation, environmental incidents, causing damage to other organizations and individuals, have the liability to make good environmental pollution and restoration. The environmental law and civil law in Article 172 of the $2015^{14}$ Civil Code: When exercising ownership rights and other property rights, the entity must comply with the law on environmental protection; If they pollute the environment, they must stop the acts of causing pollution, and take measures to remedy the consequences and compensate for damage.

12 Art. 4. Principles of environmental protection: 1. Environmental protection is the responsibilities and obligations of every agency, organization, family household and individual. 2. Environmental protection must harmonize with the economic growth, social security, assurance about the childrens right, promotion of gender equality, development and conservation of biodiversity, response to climate changes, in order to ensure the human right to live in a pure environment. 3. Environmental protection must be performed on the basis that natural resources are properly consumed and amount of waste substances are reduced to a minimum. 4. National environmental protection must conform to the regional and global environmental protection; environmental protection must ensure no harm to the national sovereignty and security. 5. Environmental protection must comply with the natural laws and characteristics, cultural and historical identities as well as the level of socio-economic development of the country. 6. Environmental protection activities must be carried out in a regular manner, and prioritize the prevention and control of environmental pollution, emergencies and degradation. 7. Any organization, family household or individual, who uses environment components and profits from the environment, is obliged to make their financial contribution to the environmental protection task. 8. Any organization, family household or individual, who causes environmental pollution, emergencies and degradation, is responsible to find remedial solutions, pay damage and assumes other responsibilities as stipulated by laws, Law on Environmental Protection 2014 of the Republic of Vietnam, Law no. 55/2014/QH13 by the National Assembly, https://vietnamlawenglish.blogspot.com/2014/06/vietnam-environmental-protection-law.html [access: 20.03.2021].

13 Art. 160 of the Law on Environmental Protection 2014: Pursuant to the Constitution of the Socialist Republic of Vietnam.

14 Art. 172 of the Civil Code of the Socialist Republic of Vietnam, Law no. 91/2015/QH13 by the National Assembly, 2015: Pursuant to the Constitution of the Socialist Republic of Vietnam, https://www .wipo.int/edocs/lexdocs/laws/en/vn/vn079en.pdf [access: 22.03.2021]. 


\subsection{Determination of organizations and individuals' liability for compensation}

In the European Union, in the ELD, the liable person is the operator ${ }^{15}$ : regardless of whether they engage in or control hazardous activities (see Annex III ${ }^{16}$ ), they must follow the rules of strict liability, exclusion and defensiveness; in other cases (not listed in Annex III), when they cause damage to the environment, such as biodiversity, it should be based on liability. The remedy is not only punitive and does not include cash penalties. Instead, the operator bears the costs of remedies to restore resources or services that have been damaged to a primary or similar state. Operator means any individual or organization, private or public unit that administers or controls professional activity, in this case as provided by national law, and decides on the technical function of the activity that has been authorized, including the owner of the license or authorization for that activity or the person who registers or notifies such an activity. The meaning of the operator, including the person liable for other relevant European directives on the environment, such as the IPPC ${ }^{17}$ Directive ( organization or entity operating or controlling the establishment, activities where required by national law, to whom economic power determines the technical function of the installation assigned ${ }^{18}$ ) and Waste Disposal Directive (any organization or which entity operates or controls the plant or, where required by national law, where economic decision-making authority over the technical function of the plant is authorized): the meaning of the operator in ELD is broader than in other directives, as it refers to all professional activities (and not only to installation or factory) and includes manufacturing or transporting hazardous goods.

The meaning of the operator includes not only the operator but also the person who directs the activities. What is certain and confirmed by the second part of the definition of operator is that the operator is not a director or officer, not a dependent, but an entrepreneur, a natural person or legal entity; conversely, from the point of view of co-author, the meaning of operator is not clear, it is too generic in the provisions of EU law. It is possible that ELD uses both verbs (operate control

15 Operator means any natural or legal, private or public person who operates or controls the occupational activity or, where this is provided for in national legislation, to whom decisive economic power over the technical functioning of such an activity has been delegated, including the holder of a permit or authorization for such an activity or the person registration or notifying such an activity. The meaning of "operator" includes the responsible person in the other relevant European directives on environment, such as the IPPC Directive.

16 See: https://www.legislation.gov.uk/eudr/2004/35/annex/iii [access: 26.03.2021].

17 See: https://ec.europa.eu/environment/archives/air/stationary/ippc/ippc_revision.htm [access: 1.04.2021].

18 M. Sousse, De la responsabilité environnementale, Environnement 2008, no. 11. 
range and direct control) to ensure that businesses in all cases are legally liable, but one cannot eliminate the use of the words operate and control.

The concept of a direct operator is not always consistent with the interpretation of Directive 2008/99 EC on environmental crimes, as penalties should be imposed on offenders, who are not only a business, but also a natural person and, in business activities, a director, an officer, an employee, etc. However, the concept of operator may be partially relevant, as under certain conditions, the acts listed in Article 3 of the ECD. ${ }^{19}$

Under Article 11 of the ELD, "Member States shall ensure that competent authorities may authorize or require third parties to take the necessary preventive or corrective measures."

Unlike the EU legislation, in Vietnam, the determination of the liability for compensation for environmental damage of organizations and individuals proceeds as follows: Organizations and individuals causing environmental pollution are liable for remedying the consequences and compensation for damage caused by their acts. In cases where individuals cause environmental pollution or degradation due to the performance of their assigned tasks, organizations shall be liable for compensation for damage according to the provisions of law. ${ }^{20}$ Thus, when businesses or economic organizations cause damage to the environment, they will be the person liable for compensation and directly liable for compensation. This is considered a group of subjects mainly liable for compensation for environmental damage in Vietnam in recent years. Forbes Vietnam (2016) identified 10 companies causing the most serious pollution in Vietnam: (1) Formosa Steel Plant; (2) Vinh Tan 2 Thermal Power Plant; (3) Vedan; (4) Mei Sheng Textiles Company; (5) Hao Duong Leather Company; (6) Sonadezi Long Thanh Joint Stock Company; (7) Hyundai Vinashin Shipbuilding Company: (8) PangRim Neotex Textile and Dyeing Company; (9) Miwon Company; (10) Hoa Binh Sugar Plant. ${ }^{21}$

These companies and businesses have caused extremely harm for humans as well as for the natural environment. In particular, there has been damage that will never be repaired or restored. This is a peculiarity of compensation for environmental damage compared to damage in other areas, where compensation may never be "sufficient" for the damage caused, especially the damage to ecosystems, landscapes destroyed due to polluting acts.

19 Art. 3 Offences. Directive 2008/99/EC of the European Parliament and of the Council of 19 November 2008 on the protection of the environment through criminal law, OJ L 328, 6.12.2008.

20 u 164 Lut bo vệ i trng Vi Nam 2014.

21 Linh Bach - Forbes Vietnam, List of pollution 2016, https://forbesvietnam.com.vn/doanh-nhan/ danh-sach-o-nhiem-89.html [access: 2.04.2021]. 
Besides, the Civil Code of Vietnam 2015 has regulations on compensation for damage caused by juridical persons (corporate entities) or their workers and trainees. The corporate body must compensate for any damage caused by any worker or staff member during assigned duties. When a juridical entity or governing body has compensated for any damage caused by its worker, then it has the right to demand the responsible worker reimburse the money as determined under the law.

Secondly, a juridical entity (body) must compensate for any damage caused by any worker or trainee during the performance of their assigned duties. The corporate body has the right to demand that this worker or trainee reimburse legal person an amount of money under the law.

For individuals who are subject to compensation, according to the general provisions of civil law, the implementation of compensation will apply as follows:

- Persons who are full eighteen years of age or older, causing damage, must pay compensation; ${ }^{22}$

- For persons under fifteen years of age who cause damage their parents must pay all damage; if the assets of their parents are not enough to compensate and the minor at fault does not have any private assets, the assets of the parents shall be used to compensate the remaining amount. Persons aged between fifteen and eighteen years of age who cause damage must compensate with their assets; If there are not enough assets to compensate, the parents must compensate the remaining amount with their assets;

- For minors, incapacitated persons with lack of legal capacity e.g. persons with cognitive difficulties and persons with limited cognition or behavior control and with a legal guardian, such guardians may use the assets of their principal; if the principal has no assets or insufficient assets to pay compensation, the guardian must compensate with his/her assets; if the guardian is able to prove that he or she was not at fault with respect to guardianship, the guardian shall not be required to use the guardian's property to compensate. ${ }^{23}$

However, according to the current law of Vietnam, there are still some open issues such as in the case of minors who cause damage to other persons, when it is first necessary to determine the precise age of the minors. Depending on the age of the minor, the Court determines who the defendant is. Regarding the determination of the litigant status of a minor causing damage as prescribed in Article 568 of the Civil Code 2015, there are currently no specific instructions. According to

22 Art. 586 of the Civil Code 2015: Capacity of individuals for liability to compensate for damage. A person of eighteen years of age or older who causes damage shall be personally liable to compensate. Pursuant to the Constitution of the Socialist Republic of Vietnam.

23 Art. 586 of the Civil Code 2015. 
the above instructions, if the person causing damage is less than 15 years old, their parents are the defendant. If the person causing damage is from 15 to under 18 years of age, they are the defendant. If the person causing damage is under the age of 18 , a guardian is the defendant. Hence, in the case of a dispute on compensation for non-contractual damage caused by a minor, it is necessary to distinguish the following three age range to determine the status of a minor's litigation: firstly, if the person is under 15-year-old; secondly, if the person is aged 15-18; third, if that person is at least 18 years old. ${ }^{24}$

\subsection{Determination of joint liability}

In accordance with EU law, a third party is only liable for damage caused by the professional activities listed in ELD Annex III: as will be explained in the next paragraph, in which case, the operator may avoid costs (or liability by claiming that damage has been caused) by a third person. Accordingly, if the government decides to require the operator to perform maintenance, "Member States will take appropriate measures to allow the operator to recover the costs incurred." ${ }^{25}$ As far as the ELD goes, it is controversial whether there is a gap within the recourse under the protection of a third party. ${ }^{26}$ In fact, the directive does not specify when the third party is legally liable. If the terms of the ELD are interpreted as establishing system rules, then the operator should only be involved in the activities listed in Annex III within the definition of "third parties" and the operator must be subject to strict liability. Conversely, if any entity interprets the scope of this protection more broadly and concludes that when a third party is not an operator under the strict liability rules of the directive, the operator may also call for safeguards, members should be allowed to ask as well as determine whether third parties are liable for intentional misconduct, negligence or even strict liability.

Besides, EU law on this matter also prescribes other liable persons. Specifically, the ELD allows member states to maintain or apply "more stringent requirements for the prevention and remediation of environmental damage, including the identification of other activities that adhere to preventive and remedial requirement

24 T.T. Duong, Determining the age of litigants in civil proceedings, Journal of People's Court 2020, no. 8.

25 Art. 8. Prevention and remediation costs, Directive 2004/35/CE of the European Parliament and of the Council of 21 April 2004 on environmental liability with regard to the prevention and remedying of environmental damage.

26 V. Fogleman, The Study on Analysis of Integrating the ELD into 11 national legal frameworks, p. 92-93, https://europa.eu/search/?queryText=fogleman+integrating\&x=0\&y=0\# [access: 4.04.2021]. 
of the Environmental Liability Directive (ELD) and identify other liable parties."27 This provision allows Member States to expand the scope of the ELD by adding activities that strictly follow the liability rules in addition to those listed in Annex III $^{28}$ or the strict rules, even excluding biodiversity destruction. This provision allows Member States to impose liability on non-business entities, such as natural persons, employees or foreign persons. ${ }^{29}$ In the case of environmental damage involving multiple countries, the EU directive 2004/35 in section 22 provides that Member States may establish rules for covering cost allocation in cases of multiple party causation. In particular, for products that may cause environmental pollution; the user may not be liable for environmental damage, but the manufacturer or the company that created the product must be liable for compensation for damage to their products when it has a negative impact on the environment. ${ }^{30}$

Although the Directive allows member states to regulate the responsibilities of businesses, the owner or the occupier of the land seems to be more difficult to deal with ${ }^{31}$ : "Such a provision would go against the principle of the polluter pays", as long as the owner is liable, even if he does not cause damage to the environment. Also according to the above principle, section $18^{32}$ of the EU's Directive 2004/35 regulates that, according to the principle of the polluter pays", operators causing environmental damage or imminent damage will in principle bear the cost of necessary preventive or remedial measures. If the competent authority acts by itself or through a third party for the operator, it should ensure that the resulting costs are recovered from the operator. The operator will ultimately be liable for

27 Article 16. Relationship with national law: 1. This Directive shall not prevent Member States from maintaining or adopting more stringent provisions in relation to the prevention and remedying of environmental damage, including the identification of additional activities to be subject to the prevention and remediation requirements of this Directive and the identification of additional responsible parties. This Directive shall not prevent Member States from adopting appropriate measures, such as the prohibition of double recovery of costs, in relation to situations where double recovery could occur as a result of concurrent action by a competent authority under this Directive and by a person whose property is affected by environmental damage.

28 Some Member States extend strict liability to other activities that are not listed in the Annex III, V. Fogleman, The Study..., p. 72-75.

29 Some Member States extend the definition of operator or apply ELD regime to other persons, V. Fogleman, The Study..., p. 59-60.

30 No. 22 of the Directive 2004/35/CE of the European Parliament and of the Council of 21 April 2004 on environmental liability with regard to the prevention and remedying of environmental damage.

31 The owner is secondary liable for environmental damage in some Member States, as United Kingdom, Poland and Hungary, V. Fogleman, The Study..., p. 76-77.

32 No. 18 of the Directive 2004/35/CE of the European Parliament and of the Council of 21 April 2004 on environmental liability with regard to the prevention and remedying of environmental damage. 
the assessment of the environmental damage and where appropriate assess the imminent risk of such damage.

In Vietnam, the joint liability to compensate for environmental damage is determined on the principle that in the event that multiple organizations individuals cause damage, the subjects liable for compensation for damage will be all of those organizations/individuals causing such damage. In amending this issue, the Civil Code 2015 clearly stated: In case multiple organizations/individuals cause damage, they must jointly compensate the affected party. Each person's indemnification for damage is determined in proportion to the degree of fault of each person; if the degree of fault cannot be determined, then they must pay equal damage. ${ }^{33}$

\section{The provisions of EU and Vietnamese laws on determining environmental damage}

\subsection{Scope of damage determination}

The main objective of the legal system in the European Community is to demonstrate the need for the application of environmental liability throughout Europe, ${ }^{34}$ in particular, the establishment of internal markets among member countries without reducing the competitiveness of member countries in the relationship between economy and environment protection in the EU common market area. EU Council enactments such as the proposed directive of civil liability for waste or the Green Book of Environment clearly state: "Different civil compensation systems for environmental damage could lead to an imbalance in competition. This means that each EU member state has its own civil laws about the compensation for damage, if there is no consensus, or there is no common document to apply to pollution cases and compensation for transnational environmental damage among EU members, this will cause difficulties and challenges. Although the Green Book on Environment ${ }^{35}$ does not contain any detailed explanation or clarification on this content, inadequacy or difference in handling a similar case in different two member states

33 Art. 616 of the Civil Code 2015.

34 M. Wilde, The EC Commission's White Paper on Environmental Liability: Issues and Implications, Journal of Environmental Law 2001, vol. 13, no. 1, p. 21-37.

35 Commission of The European Communities, Environmental issues of PVC - Green Paper, 2000, http:// aei.pitt.edu/1202/ [access: 10.04.2021]. 
will occur if some of them apply strict liability regime and other countries do not. ${ }^{36}$ It is believed that the difference between the laws of the member states regarding liability for environmental damage can lead to many environmental disputes occurring and lasting, which of course will cause an imbalance in competition, affecting the free circulation of goods on the internal market and lead to differences in the level of protection of goods. Therefore, the laws of member states need to be developed with a common rule to apply to certain cases. ${ }^{37}$ It is worth noting that the EC has been allowed to intervene wherever it is facing an issue that is part of the EC's goals and they believe that action at member state level will not be sufficient to respond. It is the "subsidiary principle". Note that it must act only to the extent necessary to achieve its goals: the "principle of proportion". The EC Treaty provides that: "The European Community will act within the limits of the powers granted to this Treaty and the goals assigned to it. In areas not under its exclusive jurisdiction, the European Community will act in accordance with the subsidiary principle, only in the case the goals of the proposed action cannot be achieved sufficiently by the member states and therefore, due to the size or impact of the action, the European Community will better address the problem if there is a linkage and coordination of countries to solve a problem together." ${ }^{38}$ Besides, the EU's Environmental Liability Directive 2004/35 also has regulations on cooperation between Member States "Where environmental damage affects or is likely to affect several Member States, those Member States should co-operate with a view to ensuring proper and effective preventive or remedial action in respect of any environmental damage" through appropriate communication, to ensure that preventive actions are taken, and that remedial measures are applied if necessary. In the case of environmental damage, the Member State from which the damage arises shall provide sufficient information to the potentially affected Member States. If a Member State discovers that damage may report the matter to the committee and other relevant

36 G. Betlem, Liability for Damage to the Environment, in: Towards a European Civil Code, ed. A.S. Hartkam et al., Alphen aan den Rijn 1998, p. 473-491. See also: M. Wilde, Extending the role of Tort as a means of Environmental Protection: an investigation of recent developments in the Law of Tort and the European Union, Brunel University London 1999, p. 151.

37 Some member states have already introduced their own schemes regarding environmental liability i.e. Sweden, Germany, Finland, Denmark, and Spain is in the process of enacting legislation. See: G. Barrenetxea, The Spanish Draft Act on Liability for Environmental Damage, Journal of Environmental Liability 1997, vol. 6, no. 1, p. 115.

38 Art. 3 of the EC treaty. 
member states to coordinate and do remedial measures. ${ }^{39}$ In section $13^{40}$ of the 2004/35 Environmental Directive it is stated that not all forms of environmental damage can be remedied through liability mechanisms. In order to ensure effective remediation, it is necessary to specify in detail who is the polluter the damage must be specific and quantifiable, and a causal relationship should be established between the damage and the polluter.

For Vietnam, the law enacted only applies within the territory of Vietnam (except for some other special cases $\left.{ }^{41}\right)$. In particular, the law on compensation for environmental damage in Vietnam has made provisions for damage arising; it is one of the prerequisite conditions for liability to pay damage in the field of environmental protection. This can be explained by the goal of applying damage to restore the original state of the affected party, ensuring their legal rights and benefits. Therefore, if there is no damage, it is not possible to discuss compensation issues even if there are other conditions such as illegal acts or fault, ${ }^{42}$ etc. Of course, the damage should have a causal relationship with the offense so that the damage compensation liability of the person causing damage is discussed.

The most typical example of compensation for damage caused by environmental pollution in Vietnam is the case of the Formosa plant (Taiwan) discharging waste and causing pollution to 04 central provinces of Vietnam. The handling of the offense committed by Ha Tinh Formosa Co., Ltd. causing environmental pollution in 04 central provinces from Ha Tinh, Quang Binh, Quang Tri and Thua Thien Hue in April 2016 is as follows: Economically, the number of dead fish washed ashore is estimated at 110 tons. Pollution levels by toxins such as Iron, Phenol, Ammonium, etc., are very high, and the sea is not safe for swimmers. One of the most difficult things to handle is that the seabed still has a suspension layer, in coral areas and hard rocks, etc. In the long term, due to the death of coral reefs and plankton, there

39 Art. 15 of the Directive 2004/35/CE of the European Parliament and of the Council of 21 April 2004 on environmental liability with regard to the prevention and remedying of environmental damage.

40 No. 13: Not all forms of environmental damage can be remedied by means of the liability mechanism. For the latter to be effective, there need to be one or more identifiable polluters, the damage should be concrete and quantifiable, and a causal link should be established between the damage and the identified polluter(s). Liability is therefore not a suitable instrument for dealing with pollution of a widespread, diffuse character, where it is impossible to link the negative environmental effects with acts or failure to act of certain individual actors, Directive 2004/35/CE of the European Parliament of the Conucil of 21 April 2004 on environmental liability with regard to the prevention and remedying of environmental damage.

41 D.V. Dai, Right to choose laws in Vietnam's international justice, Hanoi Procuratorate University, https://tks.edu.vn/thong-tin-khoa-hoc/chi-tiet/81/573 [access: 12.04.2021].

42 T.T. Phung, Environmental infringement and damage compensation liability, State Magazine and Law 2010, no. 1 . 
is a risk of disrupting the marine food chain, leading to the decline of regional biodiversity and aquatic resources, affecting long-term livelihoods of the people. Marine ecosystems are seriously affected. Immediately after discovering this environmental incident, Vietnam's Ministry of Natural Resources and Environment instructed its functional agencies to coordinate with the above provinces to conduct screening and focus on inspecting a number of major investment projects in $\mathrm{Ha}$ Tinh and Quang Binh provinces. The inspection results have found that Formosa Ha Tinh Company is the entity causing environmental pollution incidents in the four provinces with 53 offenses detected, including major ones such as arbitrarily changing technology. In particular, Formosa failed to install the filter tank for biochemical wastewater treatment plants as stipulated in the environmental impact assessment report.

After collecting all preliminary evidence and assessing the initial damage, the Ministry of Natural Resources and Environment has cooperated with other ministries and branches to work and request that Formosa acknowledge its offenses and take liability for compensating people in the four central provinces mentioned above. At first, Formosa firmly refused to admit its offenses regarding the law on environmental protection and denied its liability for the incident. It took more than two months of work, struggling through dozens of meetings, dialogues, exchanges, until 1 July 2016, when Formosa's leaders admitted their offenses and agreed to apologize to the Vietnamese people, and pay 500 million USD, and promise to invest in renovating and improving its environmental treatment system. It undertook to restore the affected marine environment, including restoring corals, seaweeds, bottom-level seafood; besides, it agreed to indemnify people who suffer from direct and indirect losses related to fishing, aquaculture and seafood processing related to polluted marine environment. ${ }^{43}$ Through the above case, it can be seen that if the Vietnamese law has specific and strict regulations on compensation for environmental damage, it will help the handling more effectively, as well as limit the cases of similar environmental pollution that are likely to arise in the future. This will ensure an extremely important principle in environmental law: the preventive principle. Therefore, in order to do this, the ways to identify environmental damage are very important, it is considered as the key to access the environmental pollution cases and solve the nature as well as the root of the problem to protect the rights of

43 Data from Legal issues for determining liability for environmental pollution damage in production and business activities of Vietnamese enterprises-Legal Sciences-Research-level scientific research by the Ministry of Justice 2019. 
the people, as well as ensure the enforcement and supremacy of a democratic society governed by a strict legal system.

\subsection{Types of compensatable damage}

In Europe, according to current regulations, EU law applies the Lugano Convention 1993 and Directive 2004/35 of the European Council for the handling of civil liability for environmental damage caused by a hazardous act that poses a risk to the Member States to this convention..$^{44}$ At the occurrence of a hazardous act, this Convention shall be applied to address the consequence of environmental pollution, according to Article 6 of the 1993 Lugano Convention, ${ }^{45}$ the governing body, the operator, or any organizational personnel are liable for damage caused by incidents affecting the environment under the circumstances specified in Article 2, paragraph 1 of the above convention, including:

(a) the production, handling, storage, use or discharge of one or more dangerous substances or any operation of a similar nature dealing with such substances;

(b) the production, culturing, handling, storage, use, destruction, disposal, release or any other operation dealing with one or more:

- genetically modified organisms which as a result of the properties of the organism, the genetic modification and the conditions under which the operation is exercised, pose a significant risk for man, the environment or property;

- micro-organisms which as a result of their properties and the conditions under which the operation is exercised pose a significant risk for man, the environment or property, such as those micro-organisms which are pathogenic or which produce toxins;

(c) the operation of an installation or site for the incineration, treatment, handling or recycling of waste, such as those installations or sites specified in Annex II, provided that the quantities involved pose a significant risk for man, the environment or property. ${ }^{46}$

Meanwhile in Vietnam today, in the field of environmental protection, damage is understood as losses caused by environmental pollution, environmental degradation and environmental incidents. These are changes in the direction of environment deterioration causing harm to the state, the community or to one or more

$44 \quad$ Art. 34 of the Lugano treaty 1993.

45 Details of the Treaty, No. 150 of the Convention on Civil Liability for Damage resulting from Activities Dangerous to the Environment, 1993.

46 See: https://rm.coe.int/168007c079 [access: 20.04.2021]. 
specific organizations and individuals. This issue is governed by the 2015 Civil Code $^{47}$ and the 2014 Law on Environmental Protection ${ }^{48}$ and a number of other legal documents. Accordingly, the acts and violations of the environmental law cause quite diverse damage but mainly manifested in the following forms:

Acts and offenses of regulations on environmental protection plans, environmental impact assessment and environmental protection schemes; acts of causing environmental pollution; acts of offenses of regulations on waste management; acts of breaching environmental protection regulations of production, business and service establishments; acts of breaching regulations on environmental protection in activities of importing machinery, equipment, means of transport, raw materials, fuels, materials, scrap and bio-preparations; import and demolition of used seagoing ships; festival activities, tourism and mineral exploitation; acts of breaching regulations on prevention, remediation, pollution, degradation and environmental incidents; breaching of biodiversity regulation such as conservation and sustainable development of natural ecosystems; conservation and sustainable development of species and conservation and sustainable development of genetic resources, etc. Organizations and individuals that offend the above law, causing damage to the environment and damage to life, health, property and lawful interests of other organizations and individuals will beliabile to provide compensation. ${ }^{49}$

In short, the acts that cause environmental damage prescribed in Article $163^{50}$ of Vietnam's Law on Environmental Protection 2014, stipulating damage caused by environmental pollution include: degradation of function and utility of the environment; damage to human life and health, property and legitimate interests of organizations and individuals as a result of the degradation in environmental function sand usefulness.

Specifically, the details are as follows: Firstly, degradation of function and utility of the environment which is a combination of inherent features of the environment, which can create favorable conditions for the development of human beings and organisms. Such degradation severely impacts on environmental components (such

47 Civil Code 2015: Pursuant to the Constitution of the Socialist Republic of Vietnam, https://www. wipo.int/edocs/lexdocs/laws/en/vn/vn079en.pdf [access: 20.04.2021].

48 See: https://vietnamlawenglish.blogspot.com/2014/06/vietnam-environmental-protection-law.html [access: 21.04.2021].

49 Art. 160 of the Law on Environmental Protection 2014: Organizations and individuals violate the law on environmental protection, causing pollution, degradation, environmental incidents, causing damage to other organizations and individuals, and being responsible for responsibility for remedying pollution, restoring environment and compensating for damage.

50 Art. 16 of the Law on Environmental Protection 2014: Pursuant to the Constitution of the Socialist Republic of Vietnam. 
as land, water, air, sound, light, organism, and things in other physical forms), all of which are required for the sustainability and development of humans and organisms on Earth and by extension, the ongoing viability of whole communities.

Secondly, damage to human life, health, property and legitimate interests of organizations and individuals as a result of the decline in the function and utility of the environment. To put it more simply, these are the loss of life, health, property and other legal benefits that the victim suffers because of the polluted environment.

When studying the aspect of legal regulations between Europe and Vietnam, it can be clearly seen that the European law has stipulated which acts would violate the specific provisions of the Environmental Law. As for Vietnam's environmental law, the regulations on identifying acts are still too generic, unclear, and violations are prescribed in many legal documents, from civil law to environmental law and other related documents, etc. In general, if there is no explanation of the law from learners and lawmakers, it will make it difficult for readers to understand the content of the legal norm as the authors have stated above.

In addition, European and Vietnamese laws also stipulate cases to exempt environmental damage compensation liability through the causes of incidents causing environmental pollution.

Under the current European law, the operator or cause of the consequences will not be liable when the cause is war, natural disaster, etc., or other provisions pursuant to Section 3, Article 8 of Directive 2004/35. ${ }^{51}$ Despite supportive and preventive measures, consequences still occur. This means that if the damage occurred for objective reasons, not the fault of the operator, or the violator, no liability would be determined. In this case, the state or the environmental insurance company will take money from the national budget to compensate. Specifically, in order to anticipate these force majeure cases, companies, production and business units must have a fund or a program called "Compulsory financial security" so that in the event of an environmental risk, this fund will be used for remedying consequences. This is to prevent evasion, or refrain from enforcing environmental protection measures when damage occurs. Moreover, in two important respects, the 1993 Lugano Convention ${ }^{52}$ does not address gaps in the protectionism of member states. First, the Convention has no obligation to plaintiffs to use the damage received by defendants to clean up the environment. Although Article $2^{53}$ (7) pro-

51 Art. 8 of the Directive 2004/35/CE of the European Parliament and of the Council of 21 April 2004 on environmental liability with regard to the prevention and remedying of environmental damage.

52 See: https://www.coe.int/en/web/conventions/full-list/-/conventions/treaty/150 [access: 23.04.2021].

53 Art. 2: Details of Treaty No. 150, Convention on Civil Liability for Damage resulting from Activities Dangerous to the Environment, https://rm.coe.int/CoERMPublicCommonSearchServices/DisplayDCTM 
vides the possibility of receiving compensation for environmental degradation, it only makes it clear that compensation will be limited to the costs of restoration measures actually taken. Therefore, Article 2 (7) states that money will only be used to restore the environment. In the absence of an indication that any compensation the plaintiff receives will be for environmental rehabilitation, there is no guarantee that cleaning measures will be taken in the most appropriate manner. Emergency procedures are to restore the environment. Secondly, while Article $18^{54}$ (1) (b) (d) of the above convention provides for the right of interest groups to apply a series of measures to prevent harm from happening or matters being made worse, it is not mentioned in the Convention.

Comparing with the above provision, Vietnamese law also has similar provisions in the case of civil liability compensation exemption if it occurs in force majeure cases according to the provisions of the Civil Code 2015. Specifically, Article $156^{55}$ states that Force majeure events are events that occur in an objective way which cannot be foreseen and cannot be overcome even though all necessary and feasible measures have been taken.

According to this regulation, an event is considered force majeure only when all three factors are present: firstly, that event is objective; secondly, the event is beyond the control of the parties in breach of contract and unforeseen and unintended consequences at the time of conclusion of the contract or in the course of contract performance until before the time of the offense; thirdly, the consequences cannot be overcome despite taking all necessary measures and permissible capabilities. Thus, according to Vietnamese law in civil relations, the party causing damage does not have to pay damage in all cases. ${ }^{56}$

As stated above, except for the liability to pay damage, Civil Code 2015 does not specify what kinds of liabilities the offending party will not bear. Meanwhile, the 2005 Commercial Law provides broader provisions on this issue and waives the offender's liability for most remedies, including damage, penalties, and suspension of contract, cancellation of contract and unilateral termination of contract. ${ }^{57}$

Content?documentId=090000168007c079 [access: 24.04.2021]. "Damage" means: a. oss of life or personal injury.

54 Art. 18: Requests by organisations, Details of Treaty No. 150 Convention on Civil Liability for Damage resulting from Activities Dangerous to the Environment.

55 See: Vietnam Civil Code 2015.

56 N.Q. Truong, T.N. Ngo, Civil liability waiver due to breach of a payment obligation in case of force majeure - COVID-19, Vietnam Journal of Legislative Research Journal 2020, no. 4.

57 Clause 1, art. 294, art. 300, art. 303, art. 308, art. 310 and art. 312 of the Law Commercial (No. 36/2005QH11), 2005. 2005 Law Commercial uses the term "suspend contract performance" and this concept is similar to "unilaterally terminate the contract" as defined in the Civil Code 2015. 
Although Vietnamese laws have tried to promulgate documents to regulate these incidents such as the Government's Decree 23/2018ND-CP on fire and explosion insurance, the scope of this decree is restricted to fire-related insurance. In addition, the law also enacts regulations on environmental deposit to prevent unfortunate events, but it is also limited to the field of mineral exploitation specified in Circular 08/2017TT-BTC on guidelines for management and use of deposits for environmental renovation and restoration for mineral exploitation activities at the Environment Protection Fund promulgated by the Minister of Finance.

With laws and regulations that are so narrow in their scope, environmental compensation arising from force majeure is much more complicated to resolve as it is so difficult to precisely assess the damage that has been caused and then to calculate the amount of compensation to be paid to the affected parties. Invariably, up until now, these situations have been arbitrarily determined by the resolution of the Vietnamese authorities. It is clear then that Vietnam really lacks mandatory requirement for businesses to buy insurance for environmental damage compensation, especially for businesses operating in industries that have a high risk of environmental pollution such as chemicals, dyeing, etc.

\section{Discussion and lessons learned for Vietnam}

\subsection{Principle of determination of the indemnifiers}

As analyzed above, while EU law clearly defines the principle of "the polluter pays", Vietnamese laws only apply this principle indirectly, through specific regulations revised in many legal documents. This can be considered as a limitation in the environmental law system in general, the law regarding liability to compensate for environmental damage. Therefore, this principle should be clearly stated in Vietnam's current policy of environmental laws, in particular in the principles of the Law on Environmental Protection. ${ }^{58}$

According to "the polluter pays" principle, those who cause environmental pollution must bear the costs for remedying and improving the polluted environment. The "polluter" here can be a person, a specific individual, or a business that pollutes

\footnotetext{
58 Art. 4 of the Law on Environmental Protection 2014: Principles of environmental protection. Pursuant to the Constitution of the Socialist Republic of Vietnam.
} 
the environment. ${ }^{59}$ These entities bear full liability for all damage caused to the environment from their activities. Not only in EU law, the polluter pays has also officially become the principle of the International Environmental Law when the Rio Declaration 1992 made it the 16th principle in the 27 principles of environment and development. ${ }^{60}$ The leaders of each nation should strive to promote the internationalization of environmental costs and the use of economic measures, because the nature of today's environmental pollution incidents is cross-border and involves many countries and territories. In addition, "the polluter pays" principle ensures the common interests of the community and without distorting international trade and investment. ${ }^{61}$ As such, the recognition of this principle in Vietnam's Environmental Protection Law not only guarantees the basis for concretizing it through specific laws, but also ensures its harmony with international environmental law, as well as the environmental laws of the EU and other countries around the world.

\subsection{Determination of organizations and individuals' liability to compensate for damage}

For organizations, the environmental damage is often very extensive and difficult to identify. Therefore, we believe that, in order to ensure that the offenders adhere to their compensation liability, depending on each specific case, it is necessary to issue more flexible regulations in implementing the liability. For example, depending on each specific case, it is possible to allow the person causing damage to the environment to pay compensation once or several times within a certain period of time from the date of applying the liability to compensate for damage. This will give the person liable for compensation enough time to implement financial solutions both to pay for the compensation and to continue to maintain production and business activities in cases where the amount of compensation is high. In this way, the offender may still be able to fulfill hisher liability to pay damage, but he will be able to reduce the risk of bankruptcy due to failure to meet the financial need at the same time, for a short period of time.

Regarding the determination of individual compensation liability, compared with Vietnamese law, it is clear that EU law has made more detailed adjustments by providing very specific provisions on operator liability. Such regulation will prevent

59 V.T. Tin, The principle of polluter pays according to Vietnam's environmental laws, Hanoi 2020.

60 H. Le Hong, Principles of international environmental law and compensation for environmental damage, Journal of Jurisprudence, September 2019, p. 34.

61 Ministry of Science, Technology and Environment, General Department of Meteorology and Hydrology, International conventions on environmental protection, Hanoi, p. 11. 
the evasion of personal liability when causing environmental damage. This will be a useful suggestion for the improvement of Vietnam's law on environmental compensation liability. Accordingly, the liabilities of the managers of production and business establishments should be clearly defined, ensuring the accountability of their decisions. Obviously, such scrutiny and enforcement is likely to have a significant impact on the business decisions, processes and work practices of operators in a wide range of industries, to the benefit of the surrounding environment and local communities.

\subsection{Ensuring the enforcement of liability to compensate for damage by insurance}

The role of insurance is to share the economic consequences of "unfortunate events" from one party (insurance buyer) to multiple parties (insurance service providers), thereby reducing the dangerous impact and potential risks of "incidents" to individuals and organizations, by causing these third parties (insurance companies) to suffer these consequences of liability for damage. Insurance maximizes risk sharing in its principles, as it allows the parties to anticipate risks and transfer risks at a cost lower than the cost incurred if the consequences occur. ${ }^{62}$ By establishing insurance premiums and underwriting conditions, the insurance market can implement improved security measures and effectively protect against the financial consequences of "incidents", this is especially important in case of repudiation or evasion of its obligation to pay damage. ${ }^{63}$

Actually, there are currently two basic types of insurance. ${ }^{64}$ One is used to compensate the insured for damage and the other is referred to as third party liability insurance. For example, if two companies engage in commercial business activities and they buy insurance from an insurance company, if in the course of operation an incident or damage occurs, the insurance company will be the indemnifier under the terms of the insurance company and the insurance buyer. Secondly, whether this is personal insurance or third party, the purpose is to compensate for damage in some cases of environmental incidents with serious consequences outside

62 See e.g. P.-J. Jost, Limited Liability and the Requirement to Purchase Insurance, International Review of Law \& Economics 1996, vol. 16, no. 2; E. Feess, U. Hege, Environmental Harm and Financial Responsibility, Geneva Papers on Risk \& Insurance - Issues \& Practice 2000, vol. 25, no. 2.

63 See: J.W. Broderick et al., Environmental Risk Management and the Role of Environmental Insurance, Environmental Quality Management 2000, vol. 10, no. 1, p. 4.

64 B.J. Richardson, Mandating environmental liability insurance, Duke Environmental Law \& Policy Forum 2001, vol. 12, no. 2, p. 293. 
the control of the operator. For instance, a chemical plant buys insurance from an insurance company, in the event of incidents causing environmental pollution as prescribed in the insurance contract, the insurance company must compensate for damage according to the insurance policy.

In Vietnam today, there are many businesses that cannot afford to compensate for damage to affected parties, especially small and medium enterprises. According to statistics, small and medium enterprises account for $93 \%$ of the total number of enterprises in the forms of state-owned enterprises, private enterprises, joint-stock companies, and foreign-invested enterprises. ${ }^{65}$ Therefore, in order to share financial hardship in this case, firms can consider some other financial solutions such as deposit or liability insurance compensation. However, in Vietnam, the measures to compensate for environmental damage have not been applied, and the liability insurance for environmental damage is only limited to the general principles in Article 167 Law on Environmental Protection 2014 and Decree $19 / 2015 N D-C^{66}$ (amended by Decree 40/2019ND-CP ${ }^{67}$ ). Accordingly, the Vietnamese state encourages insurance firms to offer liability insurance for environmental damage compensation and also encourages organizations and individuals engaged in production, business and service activities to buy insurance for environmental damage compensation liability. Organizations and individuals engaged in production, business and/or service activities likely to cause severe damage to the environment must buy insurance for environmental damage compensation liability insurance. However, they have the option to buy liability insurance for environmental damage or set up a risk reserve fund. Therefore, buying liability insurance for environmental damage is only required for organizations and individuals engaged in production, business and service activities that are likely to cause severe damage to the environment. In fact, there is a paradox that most of the organizations and individuals engaged in production, business and service activities that do not pose a risk of causing severe damage to the environment are small and medium enterprises, with weak financial situation, so when damage does occur, they still cannot afford the compensation. Therefore, they need to consider the environmental liability insurance compensation solution. Clearly, liability insurance

65 https://voer.edu.vn/m/khai-quat-chung-ve-doanh-nghiep-vua-va-nho/e72bb3b4 [access: 26.04.2021].

66 No. 19/2015/ND-CP, Decreedetailing the implementation of a number of articles of the Law on Environmental protection, https://thuvienphapluat.vn/van-ban/tai-nguyen-moi-truong/Nghi-dinh-19-2015ND-CP-huong-dan-Luat-Bao-ve-moi-truong-266743.aspx [access: 27.04.2021].

67 No. 40/2019/ND-CP, Decreeon amendments to decrees on guidelines for the Law on Environment Protection, https://thuvienphapluat.vn/van-ban/tai-nguyen-moi-truong/Nghi-dinh-40-2019-NDCP-huong-dan-Luat-bao-ve-moi-truong-413905.aspx [access: 27.04.2021]. 
for environmental damage is an important economic solution, helping Vietnam solve environmental problems, overcome pollution and share the risk burden. However, this insurance product is a difficult area, especially in controlling risks. On the other hand, when there is environmental pollution, the cost of insurance is very large, sometimes exceeding the financial capacity of the insurance company. ${ }^{68}$ In this context, learning the law of Europe is needed to further improve the efficiency of polluters' environmental damage compensation.

In Europe, the European Commission (EC) has regulations for mandatory insurance systems throughout the EU. Previously, the provisions of the $2000^{69} \mathrm{en}-$ vironmental white paper were applied. But currently, EU law has been applying the Environmental Liability Directive (ELD Directive 2004/35EC). In the process of formulating and developing regulations related to insurance, the EU adopted the above directive that the polluter pays (ELD Directive 2004/35EC) in April 2004. Despite the full implementation of ELD, there are still questions about the role of damaged environmental rehabilitation and insurance. The EC reported to the European Parliament in 2010 that the current information does not allow concrete conclusions about the validity of the EC directive in 2013, focusing on the development of the insurance industry since its implementation, including: Continued growth of environmental liability groups; Introducing the non-binding insurance model of ELD insurance. This insurance applies to all ELD risks: Key remedies; Compensation measure; Additional measures. Accordingly, in section 27 of part 1 of the above ELD directive, it is stipulated that EU countries need to take insurance measures or any other form of financial guarantee to provide effective insurance to meet financial obligations. It is be understood that the EU requires the operator to buy insurance or join other forms of guarantee to secure financial obligations, avoid cases of evasion and repudiation of the obligation to pay damage, even if bankrupt or financially incapable, the insurance company or the unit receiving the guarantee must agree to pay damage to ensure benefits for the affected parties. Subsequently, Article 14, Clause 2 of the above directive also stipulates the conditions on insurance in Appendix III. ${ }^{70}$

68 L.V. Tung, Applying liability insurance for environmental damage compensation in Vietnam: Advantages and disadvantages, Environment Magazine 2017, no. 10.

69 European Commission, White Paper on environmental liability, COM(2000) 66 final, 9 February 2000, Luxembourg 2000, https://ec.europa.eu/environment/legal/liability/pdf/el_full.pdf [access: 4.05.2021].

70 A. Endres, B. Staiger, Oekonomische Aspekte des Umwelthaftungsrecht, in: Umwelthaftung, Risikosteuerung und Versicherung, eds. M. Ahrens, J. Simon, Berlin 1996, p. 79-93; A.M. Polinksy, S. Shavell, Optimal Cleanup and Liability after Environmentally Harmful Discharges, Cambridge 1992, p. 17-24. 
However, when reviewing and analyzing the provisions of Directive 2004/35, many scholars ask why the European Commission (EC) has not built a specific system of regulations on the penalties for damage and specific methods of application. This may be explained simply because the EU is characterized by 27 member states $^{71}$ with different political and economic regimes, so insurance regulations for compensation for damage will depend on the intrinsic level of each insurer and the laws of the country where the insurer is registered. Generally, the compulsory insurance provisions in the ELD play an important role in protecting the rights and obligations of the affected parties in the cases related to compensation for environmental damage that have arisen in recent years in EU countries.

In addition, according to the latest report from Briefing, ${ }^{72}$ a survey of the entire EU insurance market determines the availability of environmental liability insurance. The survey shows that EU member states can use a variety of insurance solutions to meet market needs. It also makes it clear that EU markets are active and fac many challenges. Therefore, it is not feasible to provide the same products and methods of suitable and detailed coverage in all countries within EU. In contrast, this approach may hinder the current development of insurance products encouraged by member states. Different consumers and markets require different policies and insurance, and insurance companies in different member states respond to their market needs. In different countries, the market is at different stages of development, but the trend in providing environmental liability insurance across the EU continues to grow. ${ }^{73}$

According to the survey, from 2006 to 2014, compensation limits for energy risks (such as downstream oil exploration facilities, oil depots and electricity generation) often increased. Overall, the industry's compensation limit increased by $35 \%$ from around 2006 to 2008, reaching 10 million euros during this period, and about 11 million euros from 2011 to 2014. For companies operating in the waste sector, the required compensation limit was relatively stable from 2006 to 2009, with an average of 5 million to 8 million euros. The required compensation limit for waste companies has increased every year. This situation initially occurred in 2010 and continued in 2012. From 2012 to 2014, the average required compensation limit was from 11 million to 13 million euros. From 2006 to 2014,

71 See: https://europa.eu/european-union/about-eu/countries_en [access: 6.05.2021].

72 See: https://www.insuranceeurope.eu/insight-briefing-insurers-driving-digital-products-and-serviceseurope [access: 7.05.2021].

73 Briefing note Survey of environmental liability insurance developments, June 2014, https://docplayer.net 12383723-Briefing-note-survey-of-environmental-liability-insurance-developments.html [access: 7.05.2021]. 
the compensation limits received by manufacturing companies seemed to increase steadily, from an average of 4,5 million euros in 2006 to more than 8 million euros in 2014. ${ }^{74}$ Businesses operating in the energy, waste and industrial industries (industries that are severely prone to environmental damage, as listed in Annex III of the ELD) have increased the compensation limits for environmental risk insurance policies to meet the implementation of ELD. This makes them more likely to meet the obligations specified in the ELD and respond accordingly when an event occurs.

In October 2010, a major industrial disaster occurred in western Hungary. The operator was unable to cover the costs of the consequences the Hungarian government had not intervene, the company involved in the incident would have face bankruptcy, along with the loss of thousands of jobs. ${ }^{75}$ In this case, the insurance for environmental damage would have solved the problem of compensation for the affected parties; besides, it would have also ensure that the company would not go bankrupt and continue to provide employment for the workers.

To summarize, in this study, the authors have tried to analyze the European and Vietnamese laws on the Compensation for Non-Contractual Laws. However, this topic is so broad that the authors cannot broach all the issues involved. Instead, the author has exploited certain aspects of EU and Vietnamese legislation on this issue. As we all know that the legal system of the EU applied to the countries in the EU should be macro, where the subject of the law is related to the member states. Meanwhile, the legal system of Vietnam applies to legal entities, individuals, or legal entities under the jurisdiction of the State.

\section{Conclusion}

From the overall study, it is clear that the civil liability for environmental compensation is a fairly broad topic, it needs more research and analysis to clarify the legal provisions. A legal analysis leads to the conclusion that the harmonization of national laws with international regulations, namely the European Union, will further enhance the effectiveness of law construction and protection of the environment

74 Environmental Practice Leader EMEA, EMEA Environmental Benchmarking Report 2015, Benchmarking trends: Environmental Liability Directive Drives Shift in Purchasing of Environmental Impairment Liability Insurance, 2015, file://C:/Users/Administrator/Downloads/EMEA\%20Environmental\%20Benchmarking\%20Report\%202015-11-2015.pdf [access: 9.05.2021].

75 See: Environmental Liability, https://ec.europa.eu/environment/archives/liability/eld/studies.htm [access: 9.05.2021]. 
in Vietnam. When determining civil liability, claiming damage through polluters or an insurance company, this plays an important role in ensuring the rights and interests of the individuals involved and avoid repudiation and evasion of compensation of civil damage due to ongoing environmental pollution in Vietnam. Analyze and research laws related to the issues that have been examined in this study, according to which the legal provisions related to civil liability due to environmental damage are prescribed in the Vietnamese civil code 2015 and Environment Law 2014 on the basis of comparison with the laws of the European Union, especially Directive 2004/35.

To summarize, in this article, the authors have researched and analyzed a number of legal provisions on compensation for environmental damage in accordance with the laws of Vietnam and the European Union. In addition, the introduction of directions and orientations for building a legal model for compensating environmental damage in accordance with the current European Union model would play a very practical role in strengthening and building the current system of Vietnam's environmental laws, in order to further enhance its role and practical applicability. This will contribute to better protection for Vietnam's environment in the nearest future.

\section{Bibliography}

Anke H.T., Simplifying EU environmental legislation: reviewing the EIA Directive? Journal for European Environmental \& Planning Law 2014, vol. 11, no. 4.

Anker H.T. et al., Coping with EU Environmental Legislation - Transposition Principles and Practices, Journal of Environmental Law 2015, vol. 27, no. 1.

Barrenetxea G., The Spanish Draft Act on Liability for Environmental Damage, Journal of Environmental Liability 1997, vol. 6, no. 1.

Betlem G., Liability for Damage to the Environment, in: Towards a European Civil Code, ed. A.S. Hartkam et al., Alphen aan den Rijn 1998.

Brans E.H.P., The Environmental Liability Directive: Legal Background and Requirements, in: Equivalency Methods for Environmental Liability, ed. J. Lipton, E. Özdemiroğlu, D. Chapman, J. Peers, Dordrecht 2018.

Broderick J.W. et al., Environmental Risk Management and the Role of Environmental Insurance, Environmental Quality Management 2000, vol. 10, no. 1.

Bui K.H., Administrative responsibilities in the field of environmental today, Vietnam Legislative Studies Journal 2012, no. 22.

Communist Party of Viet Nam, The Report of the Central Committee of the Communist Party of Viet Nam of the Eighth National Party Congress on the Documents of the Ninth National Party Congress: Promoting the Nationwide Strength, Continuing Renovation, Enhancing 
Industrialisation, Modernisation, Building and Protecting the Fatherland of the Socialist Republic of Viet Nam, in: Documents of the Ninth National Party Congress, The National Political Publishing House 2001.

Costello R.Á., Reviving Rylands: how the doctrine could be used to claim compensation for environmental damages caused by fracking, Review of European, Comparative \& International Environmental Law 2014, vol. 23, no. 1.

Eckert A., Smith T.R., van Egteren H., Environmental liability in transboundary harms: Law and forum choice, The Journal of Law, Economics, \& Organization 2008, vol. 24, no. 2.

Edwards V., Significant EU Environmental Cases: 2011, Journal of Environmental Law 2012, vol. 24 , no. 1.

Endres A., Staiger B., Oekonomische Aspekte des Umwelthaftungsrecht, in: Umwelthaftung, Risikosteuerung und Versicherung, eds. M. Ahrens, J. Simon, Berlin 1996.

European Commission, White Paper on environmental liability, COM(2000) 66 final, 9 February 2000 presented by the Commission, Luxembourg 2000.

Fasoli E., The Possibilities for Nongovernmental Organizations Promoting Environmental Protection to Claim Damages in Relation to the Environment in France, Italy, the Netherlands and Portugal, Review of European Community \& International Environmental Law 2017, vol. 26, no. 1 .

Faure M.G., Jing L., Compensation for environmental damage in China: theory and practice, Pace Environmental Law Review 2014, vol. 31, no. 1.

Feess E., Hege U., Environmental Harm and Financial Responsibility, Geneva Papers on Risk \& Insurance - Issues \& Practice 2000, vol. 25, no. 2.

Fogleman V., The Study on Analysis of Integrating the ELD into 11 national legal frameworks, https://europa.eu/search/?queryText=fogleman+integrating $\& \mathrm{x}=0 \& \mathrm{y}=0 \#$ [access: 7.04.2021].

de Graaf K.J., Jans J.H., Liability of public authorities in cases of non-enforcement of environmental standards, Pace Environmental Law Review 2007, vol. 24, no. 2.

Institute of Legal Research under Ministry of Justice, Civil Liability in Environmental Field (Trach Nhiem Dan Su Trong Linh Vuc Moi Truong), Ministry-level Project 2002.

Jost P.-J., Limited Liability and the Requirement to Purchase Insurance, International Review of Law \& Economics 1996, vol. 16, no. 2.

Kistenkas F.H., Rethinking European nature conservation legislation: towards sustainable development, Journal for European Environmental \& Planning Law 2013, vol. 10, no. 1.

Le Hong H., The Concept of Environmental Law, in: Hanoi Law University Textbook on Environmental Law (Truong Dai Hoc Luat Ha Noi - Giao Trinh Luat Moi Truong), eds. H. Le Hong, H. Vu Thu, People's Police Publishing House 2007.

Le Hong H., Principles of international environmental law and compensation for environmental damage, Journal of Jurisprudence, September 2019.

Le Minh T., Form of Socialist Law (Hinh Thuc Phap Luat Xa Hoi Chu Nghia), in: Hanoi Law University Textbook on Theory of State and Law (Truong Dai Hoc Luat Ha Noi - Giao Trinh Ly Luan Nha Nuoc Va Phap Luat, ed. T. Le Minh, People's Police Publishing House 2004.

Le Minh T., The Political Regime of the SR of Viet Nam (Che Do Chinh Tri Nuoc CHXHCN Viet Nam, in: Hanoi Law University Textbook on Constitutional Law (Truong Dai Hoc Luat Ha Noi - Giao Trinh Luat Hien Phap), eds. T. Vinh Thang, V. Hong Anh, People's Police Publishing House 2007. 
Maes F., Marine Resource Damage Assessment. Liability and Compensation for Environmental Damage. Law and Political Science, Dodrecht 2005.

Nguyen T.T., Law of International Treaties (Chuong IV Luat Dieu Uoc Quoc Te), in: Hanoi Law University Textbook on International Law (Truong Dai Hoc Luat Ha Noi - Giao Trinh Luat Quoc Te), eds. A. Le Mai, V.L. Nguyen, People's Police Publishing House 2004.

Nguyen T.T., On The Settlement Of The Relation Between International Law And Domestic Law, in: Vietnamese Law (Ve Viec Giai Quyet Moi Quan He Giua Phap Luat Quoc Te Va Phap Luat Quoc Gia Trong Phap Luat Viet Nam), State and Law 2004, vol. 39, no. 9.

Nguyen Thi B.N., Legal provisions on compensation for health and life damages caused by environmental pollution: Actual situation and recommendations, Vietnam Academy of Social Sciences Institute of State and Law 2013, no. 12.

Organization for Economic Co-operation and Development (OECD), The Polluter-Pays Principle OECD Analysis And Recommendations Environment Directorate, Paris 1992.

$\mathrm{Vu}$ Thu Hanh, Tran Tien Anh, the right to sue for damage due to violations of environmental law in Vietnam - Legal basis and implementation process, Pannature. Hanoi 2011.

Phung T.T., Environmental infringement and damage compensation liability, State Magazine and Law 2010, no. 1.

Phung T.T., Infringement of the environment and responsibility for compensation, Vietnam Academy of Social Sciences Institute of State and Law 2010, no. 1.

Phung T.T., Liability for non-contractual damage, Hanoi 2016.

Pham H.N., Legal provisions on damage, determination of damage, cause by environmental pollution, and perfect construction orientation, Vietnam Academy of Social Sciences Institute of State and Law 2011, no. 1.

Pham H.N., Liability for compensation for environmental damage, State and Law Review 2008, no. 6 .

Polinksy A.M., Shavell S., Optimal Cleanup and Liability after Environmentally Harmful Discharges, Cambridge 1992.

Richardson B.J., Mandating environmental liability insurance, Duke Environmental Law \& Policy Forum 2001, vo. 12, no. 2.

de Sadeleer N., La directive 2004/35/CE relative à la responsabilité environnementale: avancée ou recul pour le droit de lenvironnement des Etats membres?, in: Les responsabilités environnementales dans l'espace Européen, eds. B. Dubuisson, G. Viney, Brussels 2005.

de Sadeleer N., Preliminary Reference on Environmental Liability and the Polluter Pays Principle: Case C-534/13, Fipa, Review of European, Comparative \& International Environmental Law 2015, vol. 24, no. 2.

Shelton D.L., Kiss A., Strict Liability in International Environmental Law, Berlin 2007.

United Nations Sustainable Development, United Nations Conference on Environment \& Development, Rio de Janeiro, Brazil, 3 to 14 June 1992. AGENDA 21, https://sustainabledevelopment.un.org/outcomedocuments/agenda21 [access: 1.05.2021].

Sousse M., De la responsabilité environnementale, Environnement 2008, no. 11.

Tin V.T., The principle of polluter pays according to Vietnam's environmental laws, Hanoi 2020.

Vo Thi M.H., The Laws on ensuring the right to claim compensation for violations of environmental in Vietnam, Institute of State and Law, Vietnam Academy of Social Sciences 2012, no. 1.

Truong N.Q., Ngo T.N., Civil liability waiver due to breach of a payment obligation in case of force majeure - COVID-19, Vietnam Journal of Legislative Research Journal 2020, no. 4. 
Tung L.V., Applying liability insurance for environmental damage compensation in Vietnam: Advantages and disadvantages, Environment Magazine 2017, no. 10.

Wilde M., Civil liability for environmental damage. Comparative analysis of law and policy in Europe and the United States, Alphen aan den Rijn 2002.

Wilde M., The EC Commission's White Paper on Environmental Liability: Issues and Implications, Journal of Environmental Law 2001, vol. 13, no. 1. 